\title{
Performance of bioretention experimental devices: contrasting laboratory and field scales through controlled experiments
}

\section{Performance de dispositivos experimentais de bioretenção: comparação entre escala de laboratório e de campo a partir de experimentos controlados}

\author{
Marina Batalini de Macedo ${ }^{1}$, César Ambrogi Ferreira do Lago ${ }^{1}$, Eduardo Mario Mendiondo ${ }^{1}$ and \\ Vladimir Caramori Borges de Souza ${ }^{2}$ \\ ${ }^{1}$ Universidade de São Paulo, São Carlos, SP, Brazil \\ ${ }^{2}$ Universidade Federal do Alagoas, Maceió, AL, Brazil \\ E-mails: marina_batalini@hotmail.com (MBM), cesar-lago@hotmail.com (CAFL), e.mario.mendiondo@gmail.com (EMM), \\ vcaramori@yahoo.com (VCBS)
}

\begin{abstract}
Studying the performance of LID devices on a laboratory scale has the advantage of flexible layouts, so that more factors can be tested. However, they do not always correspond to what happens on a real scale of application. This paper focuses on a comparative analysis between two bioretention experimental devices considering field and laboratory scales. Based on this comparison, our understanding can be enhanced to extrapolate the results. Flow rate and duration were used as the main equivalence parameters. However, these parameters were insufficient to ensure similarity in the results. We proposed to include control volume, an application rate and an equivalent net depth as new parameters. Further research should test the variation of these parameters.
\end{abstract}

Keywords: SUDS; Stormwater control; Water retention; Pollutant removal.

\section{RESUMO}

Estudos da performance em laboratório possuem a vantagem de layouts flexíveis, podendo testar mais fatores. No entanto, nem sempre correspondem ao que acontece na escala real de aplicação. Este estudo foca em uma análise comparativa entre dispositivos experimentais de bioretenção em escala de campo e em escala de laboratório. A partir dessa comparação, é possível avançar na compreensão para extrapolação dos resultados. Como principais parâmetros de equivalência, foram utilizados a taxa de fluxo e a duração. No entanto, observou-se que estes parâmetros foram insuficientes para garantia de similaridade nos resultados. Indicamos como novos parâmetros a serem incorporados o volume de controle, taxa de aplicação e altura equivalente útil. Novos estudos com a variação destes parâmetros devem ser feitos.

Palavras-chave: SUDS; Controle de águas pluviais; Retenção hídrica; Remoção de poluentes. 
Performance of bioretention experimental devices: contrasting laboratory and field scales through controlled experiments

\section{VARIABLES LIST}

$A_{\text {field }}=$ Surface area of bioretention device in field $[\mathrm{m}]$;

$A_{\text {lab }}=$ Surface area of bioretention box in laboratory $[\mathrm{m}]$;

$A_{w}=$ Surface receiving precipitation for the catchment related to the bioretention in the field $\left[\mathrm{m}^{2}\right]$;

$C(t)=$ Concentration, at time $\mathrm{t}[\mathrm{mg} / \mathrm{L}]$;

$F_{m}=$ Average flow rate $[\mathrm{cm} / \mathrm{h}]$;

$H_{\text {equivalent }}=$ Equivalent net depth $[\mathrm{m}]$;

$H_{\text {gravel }}=$ Depth of the gravel layer $[\mathrm{m}]$;

$H_{\text {sand }}=$ Depth of the sand layer $[\mathrm{m}]$;

$H_{\text {soil }}=$ Depth of the soil layer $[\mathrm{m}]$;

$I(t)=$ Percolated flow into the ground $[\mathrm{L} / \mathrm{min}]$;

$M_{I}(t)=$ Infiltrated/treated pollutant mass by the LID practice $[\mathrm{g}]$;

$M_{i n}(t)=$ Pollutant mass in the inflow runoff $[\mathrm{g}]$;

$M_{\text {out }}(t)=$ Pollutant mass in the outflow $[\mathrm{g}]$;

$M_{p}(t)=$ Pollutant mass in the precipitation, directly over the bioretention basin $[\mathrm{g}]$;

$M_{s}(t)=$ Stored pollutant mass, including positive or negative reactions due to internal processes, i.e. sorption, degradation, etc., in the bioretention basin $[\mathrm{g}]$;

$n=$ Total number of campaigns;

$P(t)=$ Precipitation $[\mathrm{mm}]$;

$Q(t)=$ Water flow at time $\mathrm{t}[\mathrm{L} / \mathrm{min}]$;

$Q_{i n}(t)=$ Inflow discharge $[\mathrm{L} / \mathrm{min}]$;

$Q_{\text {med feeld }}=$ Average inflow, in field $[\mathrm{L} / \mathrm{h}]$;

$Q_{\text {out }}(t)=$ Outflow discharge $[\mathrm{L} / \mathrm{min}]$;

$S(t)=$ Storage volume in the bioretention basin [L];

$t=$ Analyzed time interval [min];

$t_{\text {feld }}=$ Duration of the event in field $[\mathrm{h}]$;

$t_{i}=$ Duration of campaign $i[\mathrm{~h}]$;

$V_{\text {control }}=$ Control volume, equivalent with total inlet volume [L];

$V_{i, \text { total }}=$ Total inlet volume, considering campaign $i[\mathrm{~L}]$;

$\Delta t=$ Considered time interval [min].

\section{INTRODUCTION}

The rapid growth of cities and the lack of urban and territorial planning are causing an increase in soil sealing and, consequently, an increase in runoff. As a result, traditional urban drainage systems are frequently overloaded, often leading to urban floods. The extreme precipitation events are already a major cause of natural disasters in Brazil (SANTOS, 2007; YOUNG; AGUIAR; SOUZA, 2015), causing floods, landslides, etc. In addition, according to the predictions of climate change, this scenario is likely to become worse (VALVERDE; MARENGO, 2010; MARENGO et al., 2010). Therefore, low impact development (LID) practices have appeared as alternative and sustainable systems for urban drainage, capable of reducing runoff at the source, reestablishing the infiltration of water into the soil and reducing social and environmental impacts.

LID practices include different approaches, ranging from participatory planning, environmental education and runoff reducing devices (FLETCHER; ANDRIEU; HAMEL, 2013). These devices can be used on many scales, such as source control, micro and macro drainage (MARSALEK; SCHREIER, 2009). Examples could be green roofs, infiltration trenches, permeable pavements, wetponds and bioretention cells (URBONAS; STAHRE, 1993; BAPTISTA; NASCIMENTO; BARRAUD, 2005; ERICKSON; WEISS; GULLIVER, 2013). In Brazil, recent studies have addressed the use of these devices, focusing mainly on infiltration trenches and wells (LUCAS, 2011; LUCAS et al., 2015; GUTIERREZ, 2011). However, to broaden the knowledge of a greater number of devices, this paper outlines the operation of a bioretention system.

Bioretention systems have the dual function of qualitative and quantitative treatment, as they retain/detain the runoff while removing pollutant loads. According to Erickson, Weiss and Gulliver (2013) and Laurenson et al. (2013), qualitative treatment occurs through the physical-chemical process of filtration, sedimentation and sorption, as well as the biological process of microbiological degradation and phytoremediation.

Considerable research efforts have been made to evaluate the bioretention system performance, prevailing studies on a laboratory scale. Wang et al. $(2015,2016)$ investigated metal removal $(\mathrm{Cd}, \mathrm{Cu}, \mathrm{Pb})$, testing different filtering media with experiments conducted in bioretention columns. They found a removal rate above $90 \%$ in the percolation outlet. Rycewicz-Borecki, McLean and Dupont (2017) also evaluated the removal of metals $\mathrm{Cu}, \mathrm{Pb}$, and $\mathrm{Zn}$, carrying out experiments on a laboratory scale. Their results reported metal removal above $92 \%$ and demonstrated accumulation in the macrophytes used to help the treatment. Nevertheless, studies conducted in the laboratory are not limited to metals. Chahal, Shi and Flury (2016), Liu et al. (2014) and Bratieres et al. (2008) evaluated the nutrient removal in a bioretention system and reported removal efficiency ranging from 80 to $99 \%$.

Field scale studies have also started to increase. Some examples are listed here. In their paper, Mangangka et al. (2015) focused on how hydraulic and hydrologic factors affect the pollutant removal in field conditions in dry and rainy seasons. As a main result, they observed that the antecedent dry period has a great influence on the nitrification and export process of nitrate. Petterson et al. (2016) and Lucke and Nichols (2015) investigated the removal of pathogens, nutrients and metals. For the pathogen removal, Petterson et al. (2016) observed that the removal performance for microbial (viral, bacterial and protozoan) varied significantly between them and between the baseline conditions. As for the nutrients and metals, Lucke and Nichols (2015) obtained good 
removal rates for total phosphorus, the only pollutant effectively removed from all basins investigated, and acceptable limits for metals in all basins, even after 10 years of operation. Davis (2007), Hatt, Fletcher and Deletic (2009), Winston, Luell and Hunt (2011) and Brown and Hunt (2012) found nutrient removal rates varying from 3.2 to $64 \%$ and even nitrogen export - and removal rates from 57 to $83 \%$ for metals.

Laboratory scale studies have some advantages: environmental conditions can be controlled to conduct a more in-depth investigation of the treatment processes; and different factors that influence the treatment mechanisms can be used so as to identify the key-factor. In addition, there is no temporal dependence on the occurrence of storms and a greater amount of analyses can be made in a shorter time. However, what takes place in the laboratory will not necessarily occur in the field. In many cases, the results cannot be extrapolated without further analyses. When comparing the laboratory and field studies mentioned here, it can be observed that laboratory experiments reported higher pollutant removal than field experiments (around 90\% and 60\%, respectively).

Despite the importance of these studies developed in the laboratory and in the field, only a few have addressed the two scales of analysis in an integrated way. One example is a study conducted by Hsieh and Davis (2005), which investigated the removal rates in column experiments and bioretentions operating in the field, evaluating the filtering media characteristics in their behavior. Their results demonstrate higher efficiencies for field systems when analyzing parameters of mineral contamination ( $\mathrm{Pb}$ and TSS) and higher efficiencies for the columns for parameters that indicate nutrient contamination ( $\mathrm{TP}, \mathrm{NH}_{4}$, and $\mathrm{NO}_{2,3}$ ). Other studies have also made comparisons between column studies in the laboratory with bioretention cells in the field to evaluate specific characteristics: Li and Davis (2008) evaluated the removal, penetration and clogging of solid particles, using variable flow rates. Zhang et al. (2012) analyzed the effect of temperature on the bacterial removal, firstly studying the behavior in the field and secondly varying the conditions in the column studies. They realized that the results on a laboratory scale could not be extrapolated to the field, because they presented different hydraulic dynamics.

Davis et al. (2006) tested another configuration for a laboratory experiment, in addition to the column test already widely used. In this study, the laboratory scale was made from bioretention box experiments with small and large dimensions. The first one has closer dimensions to field bioretention facilities, while the second one has more flexible characteristics for experimental variations, but with less similarity with the field. The study was conducted in the laboratory and in the field to evaluate the nutrient removal under controlled conditions, applying the same flow rate $(4.1 \mathrm{~cm} / \mathrm{h})$ and the same duration. Despite the fact that they obtained variations between the results in the two scales, it could be concluded that nitrate removal is small due to nitrification.

From the literature, it can be observed that even studies with integrated evaluation have a great variation in the results obtained for the two scales, making it difficult to extrapolate and compare them. Moreover, these studies did not explain the reasons for the differences and how to approach the comparison more assertively.

Therefore, this paper focused on the development of bioretention experimental devices in the laboratory and in the field, addressing the problems and limitations when comparing the results for different scales. This can provide a better understanding and a step forward in raising the elements to make a better extrapolation of the results obtained in the laboratory and future integrated studies. In addition, considering that there are still few studies developed on bioretention in Brazil, this paper intends to broaden the knowledge of this technique in a subtropical climate. Based on the controlled experiments, the hydraulic and qualitative treatment mechanisms can be identified, as well as suggestions for better sizing and design.

\section{METHODOLOGY}

Two experimental scales - laboratory and field - were studied in order to compare their performance results. The water and pollutant mass balance quantification, the study area characterization and how we determine the adequate flow rate to ensure a similarity between the two scales are presented in the next sections.

\section{Quali-quantitative data collection}

To determine the system performance and efficiency, the variables of the water and pollutant mass balance have to be determined numerically. In this study, the relevant variables to determine the balances were inflow, outflow, stored volume, precipitated volume and percolation flow, as shown in the diagram (Figure 1). Equations 1 and 2 (adapted from ERICKSON; WEISS; GULLIVER, 2013) were used to quantify the water balance and mass balance, respectively.

$$
\begin{aligned}
& S(t)=\left(Q_{\text {in }}(t) t+P(t) A_{w}\right)-\left(Q_{\text {out }}(t) t+I(t) t\right) \\
& M_{s}(t)=\left(M_{\text {in }}+M_{P}\right)-\left(M_{\text {out }}(t)+M_{I}(t)\right)
\end{aligned}
$$

where: $A_{w}=$ Surface receiving precipitation for the catchment related to the bioretention in the field $\left[\mathrm{m}^{2}\right] ; I(t)=$ Percolated flow into the ground $[\mathrm{L} / \mathrm{min}] ; M_{I}(t)=$ Infiltrated/treated pollutant mass by the LID practice $[\mathrm{g}] ; M_{i n}(t)=$ Pollutant mass in the

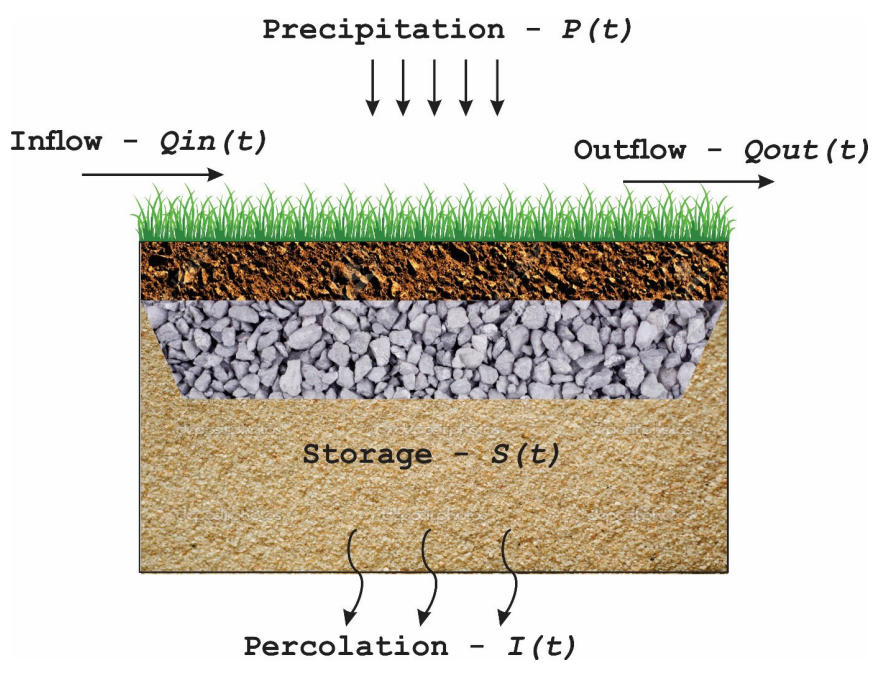

Figure 1. Bioretention diagram representing the laboratory and field scales and the water balance variables. 
inflow runoff $[\mathrm{g}] ; M_{\text {out }}(t)=$ Pollutant mass in the outflow $[\mathrm{g}]$; $M_{s}(t)=$ Stored pollutant mass, including positive or negative reactions due to internal processes, i.e. sorption, degradation, etc., in the bioretention basin $[\mathrm{g}] ; M_{P}(t)=$ Pollutant mass in the precipitation, directly over the bioretention basin $[\mathrm{g}] ; P(t)=$ Precipitation $[\mathrm{mm}]$; $Q_{i n}(t)=$ Inflow discharge $[\mathrm{L} / \mathrm{min}] ; Q_{\text {out }}(t)=$ Outflow discharge $[\mathrm{L} / \mathrm{min}] ; S(t)=$ Storage volume in the bioretention basin $[\mathrm{L}]$; $t=$ Analyzed time interval [min].

On a laboratory scale, quantitative and qualitative data were sampled manually every 5 min for inflow, outflow and percolation (until there was no more percolation), and automatically for storage, using the humidity sensor TDR CS616 (Table 1).

The moisture sensor provides volume data of water fraction for each corresponding sensor range. In this case, six sensors were used, two related to the vegetated soil layer and four corresponding to the filtering media (sand + gravel). The sensor ranges were delimited according to their signal pickup radius, determined as $0.5 \mathrm{~m}$ and the boundaries of the layers. For each range, the moisture was converted to the volume of stored water by multiplying the fraction by the respective total volume of voids. Finally, the total stored volume was calculated as the sum of the value obtained for each range.

On the other hand, on the field scale, the quantitative data was automatically collected, using a level sensor HOBO-WATER U20L-02 (Table 1). For the inflow and outflow, the level sensor was associated with a weir (composite section and triangular section), so that the flow could be quantified. For storage, the level sensors were installed inside the piezometers presently found along the bioretention device. This method can calculate the stored volume converted to a liquid level within the bioretention cell, but may underestimate the total amount, as it disregards the water retention in the pores (in the form of moisture). As for the qualitative sample collection, for the inflow, an automatic sampler with a time interval of $5 \mathrm{~min}$ was used and for the storage and outflow, the samples were collected manually with a time interval of $10 \mathrm{~min}$, until there was no more outflow.

The difference between the two acquisition methods adopted for the storage calculation on the laboratory and in the field scale will be analyzed in the Results and Discussion section.

To simulate the diffuse pollution in the runoff, a synthetic flow was made from the collection of solid particles found in the pavements relative to each catchment, according to the methodology proposed by Maglionico (1998). The contaminants were collected by sweeping the pavement which had a greater accumulation of sediment, predetermined and fixed for all the collections (red lines in Figure 2). The antecedent dry period for each collection was determined, in order to relate the accumulation of sediments with the period without rain. Subsequently, the collected contaminant particles were mixed with well water (without additional chlorine) in tanks containing the total input volume to prepare the synthetic flow. The tanks were kept at a constant mixture throughout the duration of the experiment. For this study, this effluent preparation method was chosen because it is cheaper than preparing it by reagents, it has a simpler application and it resembles the real conditions of the catchment area, although there is no need for ensuring complete representativeness.

The water quality parameters analyzed were selected to represent organic matter contamination - chemical organic demand (COD) and total organic carbon (TOC) - nutrient contamination - nitrite (NO2), nitrate (NO3), ammonia (NH3) e phosphate (PO4) - solid contamination - sedimentable solids (SS) - and metals contamination - iron (Fe), zinc ( $\mathrm{Zn})$ and cadmium (Cd). The analysis follows the methods proposed in the Standard Methods for Examination of Water and Wastewater (APHA, 1992). For each variable of the pollutant mass balance, the total load was quantified according to Equation 3, integrating the total time of the analyzed hydrographs.

$$
\text { Load }=\int C(t) Q(t) d t=\sum C(t) Q(t) \Delta t
$$

where: $C(t)=$ Concentration, at time $\mathrm{t}[\mathrm{mg} / \mathrm{L}] ; Q(t)=$ Water flow at time $\mathrm{t}[\mathrm{L} / \mathrm{min}] ; \Delta t=$ Considered time interval [min].

\section{Study area and experimental scales.}

The two devices are situated in São Carlos, SP, Brazil at the University of Sao Paulo campus (USP campus 1 and 2) (Figure 2). For each one of the scales, the catchment was delimitated and, consequently, the contribution area for the diffuse pollution. Table 1 presents the specific characteristics for both scales.

In this characterization stage, we also established the parameter equivalent net depth $\left(\mathrm{H}_{\text {equivalent }}\right)$, defined as a height value equivalent to the actual zone of the bioretention responsible for the qualitative treatment. This value is calculated from the ratio of the net storage volume through the bioretention surface area. That is, this parameter represents a proportion between the net retention capacity of the device inside the filtering media and its application surface area, which will receive the runoff, resulting in a value representing the real treatment zone within the technique. Therefore, higher values represent larger zones and, consequently, greater treatment capacity. The $\mathrm{H}_{\text {equivalent }}$ was defined as a way to standardize and parameterize the measurement of the qualitative treatment zone of a bioretention, regardless of its configuration, scale and type of filtering material.

For the laboratory scale, a bioretention box experiment with small dimensions ( $1 \mathrm{~m} \times 1 \mathrm{~m} \times 1.45 \mathrm{~m}$ ), according to those proposed by Davis et al. (2006), was constructed to better evaluate the keyfactors that play an important role in the efficiency of a bioretention practice. In this scale, the $\mathrm{H}_{\text {equivalent }}$ calculated is $0.32 \mathrm{~m}$, as observed in Table 1. The laboratory device consists of three layers, the first of which is a natural soil - predominantly sandy -, serving as a medium for vegetation fixation (garden grass, Axonopus compressus),

Table 1. Specifications of the experimental scales analyzed.

\begin{tabular}{ccccccc}
\hline & $\begin{array}{c}\text { Surface } \\
\text { area }\left(\mathbf{m}^{2}\right)\end{array}$ & $\begin{array}{c}\mathbf{H} \text { soil } \\
(\mathbf{m})\end{array}$ & $\begin{array}{c}\mathbf{H} \text { gravel } \\
(\mathbf{m})\end{array}$ & $\begin{array}{c}\mathbf{H} \text { sand } \\
(\mathbf{m})\end{array}$ & $\begin{array}{c}\mathbf{H}_{\text {equivalent }}=\text { Storage/Surface area } \\
\left(\mathbf{m}^{3} / \mathbf{m}^{2}\right)\end{array}$ & $\begin{array}{c}\text { Water balance variables } \\
\text { monitored }\end{array}$ \\
\hline Lab scale & 60.63 & 0.2 & 0.3 & 0.5 & 0.32 & $\operatorname{Qin}(t) \cdot \operatorname{Qout}(t) . S(t) . I(t)$ \\
Field scale & 1.45 & 0.5 & 0.7 & 2 & 1.02 & $\operatorname{Qin}(t) . \operatorname{Qout}(t) . S(t) . P(t)$ \\
\hline
\end{tabular}



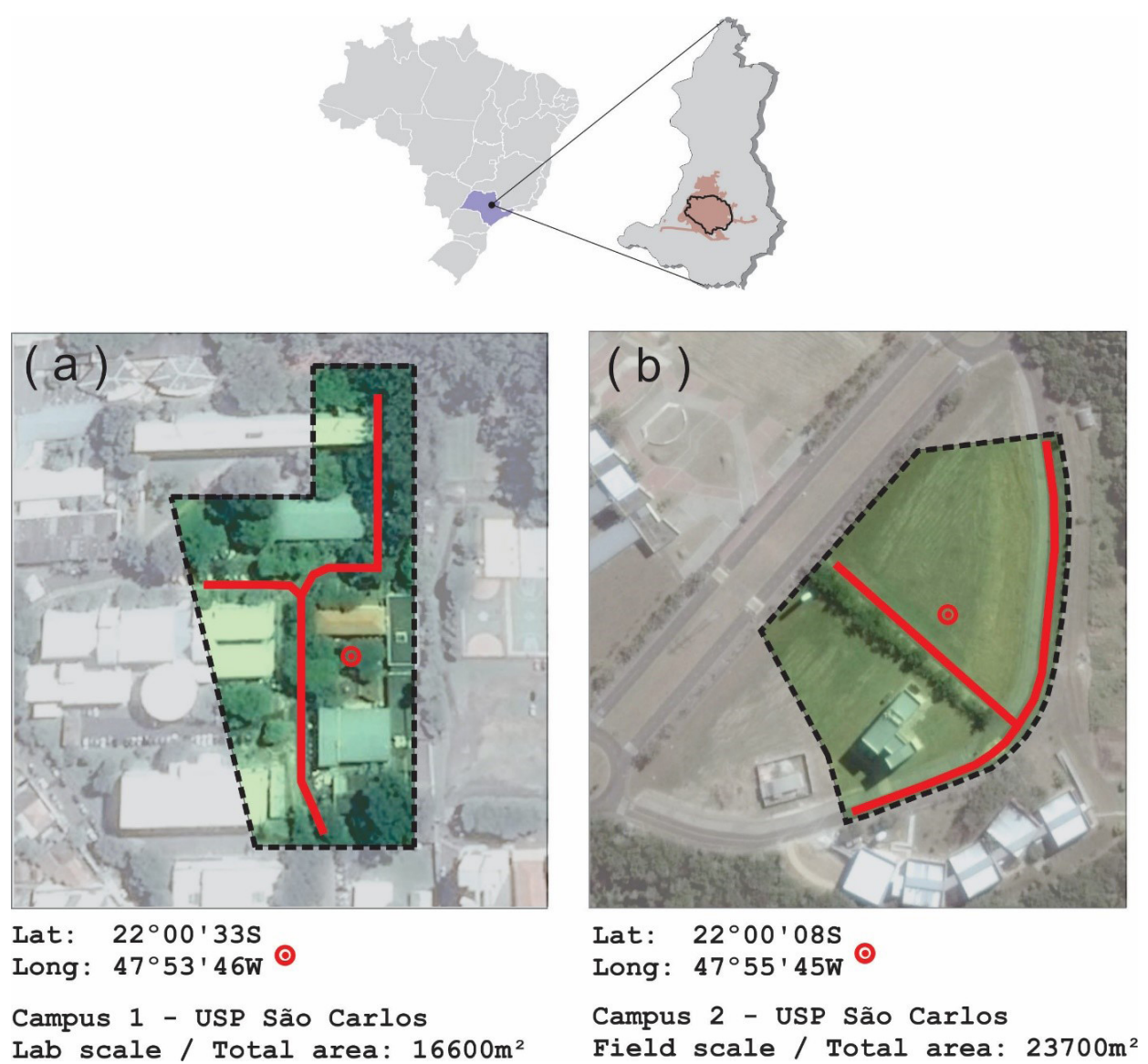

Figure 2. Study areas for laboratory scale (a) and field scale (b). The diffuse pollution was collected in the pathways represented by the red lines.

followed by gravel and sand, according to the arrangement shown in Figure 1. This filtering media was chosen to achieve the dual function of water retention and water qualitative treatment. For this scale, the catchment area corresponding to the contribution in diffuse pollution is completed urbanized, with a high level of surface paving. The runoff was simulated using a tank-pump-dispenser flow system, mixed with the diffuse pollution collected, operating at constant flow and adjusted to simulate selected rainfall intensity. The water balance variables monitored were: inflow $Q_{\text {in }}(t)$, outflow $\mathrm{Q}_{\text {out }}(\mathrm{t})$ and percolation $\mathrm{I}(\mathrm{t})$.

Regarding the field scale, the bioretention device is situated at USP campus 2. On this scale, the device receives a runoff of a catchment with a total area of $2.3 \mathrm{ha}$. For this dimension, a micro drainage scale is considered (Figure $2 \mathrm{~b}$ ). The area is still mostly characterized as crawling vegetation, having only a few pathways. Therefore, the main contributions to the runoff are the automobile and pedestrian ways and a waterproof area relative to the campus building. The bioretention device has a surface area of $60.63 \mathrm{~m}^{2}$ and $3.2 \mathrm{~m}$ depth (Table 1). From the ratio of net volume and surface area, a $\mathrm{H}_{\text {equivalent }}$ of $1.02 \mathrm{~m}$ was determined. This device has the same filtering media composition as the laboratory scale (gravel followed by sand, as shown in Figure 1) covered by local natural soil, with a sandy-loamy feature. The superficial layer was vegetated with Brachiaria sp., selected to maintain the landscape integration and soil stabilization. On this scale, the water balance variables monitored were: precipitation $\mathrm{P}(\mathrm{t})$, inflow $\mathrm{Q}_{\text {in }}(\mathrm{t})$, outflow $\mathrm{Q}_{\text {out }}(\mathrm{t})$ and storage $\mathrm{S}(\mathrm{t})$.

The diffuse pollution was collected manually along a contribution area of 1.6 ha at USP campus 1 (Figure $2 \mathrm{a}$ - red line) for the laboratory scale and along the catchment area of 2.3 ha for the bioretention in the field (Figure $2 \mathrm{~b}$ - red line), after a dry period, as proposed by Maglionico (1998) and described in the previous section.

\section{Comparing the scales of analysis}

Comparing the two experimental scales requires establishing an equivalence relation between them. For this study, we proposed this equivalence relation based on three main parameters: Precipitation equivalent to real events, Flow rate and Duration. In this section, each one of these parameters will be explained. Figure 3 shows a scheme with the relations established between these three parameters (precipitation equivalent to real events, flow rate and duration) and the two scales.

In order for the controlled experiments in the bioretention box to correlate with the real events occurring in the field, calculations were made to establish the values of precipitation equivalent to real events. Based on a computational simulation (BIRENICE method, ROSA, 2016) and field data acquisition during rainfall events (3 events during 2015), values of the total depth precipitated 
and total drained volume were determined, corresponding to a small and strong event. These equivalent values were used as upper and lower limits to regulate the flow rate in the laboratory controlled experiments, maintaining the proper correspondence to the surface area of the bioretention box $\left(\mathrm{A}_{\mathrm{lab}}\right)$.

After ensuring the relationship between the controlled events in the laboratory with the non-controlled events in the field (or real) for the variable drained volume, it was necessary to establish a correspondence with the controlled experiments in the field. To accomplish this purpose, we set a fixed flow rate as a comparison parameter, which was calculated by averaging the flow rate used on the laboratory scale, according to Equation 4.

$F_{m}=\frac{\sum_{i=1}^{n} 10 x V_{i, t o t a l} /\left(A_{\text {lab }} x t_{i}\right)}{n}$

where: $F_{m}=$ Average flow rate $[\mathrm{cm} / \mathrm{h}] ; A_{l a b}=$ Surface area of bioretention box in the laboratory $[\mathrm{m}] ; n=$ Total number of campaigns; $V_{i, \text { total }}=$ Total inlet volume, considering campaign $i[\mathrm{~L}] ; t_{i}=$ Duration of campaign $i[\mathrm{~h}]$.

Finally, after setting the flow rate value to be used for the controlled event in the field, it was necessary to establish the required duration of the event. Equation 5 presents the calculations for this parameter, based on the maximum capacity water tank (used as the control volume) and the surface area for the bioretention device in the field $\left(\mathrm{A}_{\text {field }}\right)$. The flow rate was transformed into an average inflow relative to the duration determined (Equation 6) in order to facilitate the operation throughout the experiment.

$$
\begin{gathered}
t_{\text {field }}=\frac{10 x V_{\text {control }}}{A_{\text {field }} x F_{m}} \\
Q_{\text {med field }}=\frac{V_{\text {control }}}{t_{\text {field }}}
\end{gathered}
$$

where: $F_{m}=$ Average flow rate $[\mathrm{cm} / \mathrm{h}] ; Q_{\text {med feld }}=$ Average inflow, in field $[\mathrm{L} / \mathrm{h}] ; A_{\text {field }}=$ Surface area of bioretention device in field $[\mathrm{m}] ; V_{\text {control }}=$ Control volume, equivalent with total inlet volume $[\mathrm{L}] ; t_{\text {field }}=$ Duration of the event in field $[\mathrm{h}]$.

\section{Equivalent precipitation depth}

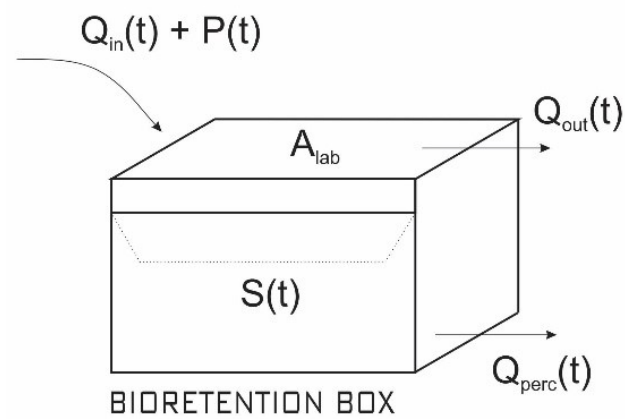

Variable Flow Rate $(\mathrm{F})$

Variable Duration $\left(\mathrm{t}_{\mathrm{tab}}\right)$

Average Flow Rate $\left(\mathrm{F}_{\mathrm{m}}\right)$

$F_{m}=\frac{\bar{V} \cdot 10}{\bar{t}_{\mathrm{lab}} \cdot A_{\mathrm{lab}}}$
Other studies addressing the laboratory and field experiments in an integrated way (HSIEH; DAVIS, 2005; DAVIS et al., 2006; LI; DAVIS, 2008; ZHANG et al., 2012) did not establish a correspondence relationship between the two scales of analysis. We propose here a comparison based on the relationships between the equivalent precipitation, flow rate and duration. Therefore, the results for the two scales were evaluated and compared, showing the problems and variations found for this proposed method. Finally, suggestions for future comparative studies were presented.

\section{Campaigns}

Regarding the laboratory scale, six campaigns were made to evaluate the bioretention quali-quantitative efficiency. The inflow ranged from $691 \mathrm{~L} / \mathrm{h}$ to $2667 \mathrm{~L} / \mathrm{h}$ (equivalent to a flow rate ranging from $47.5 \mathrm{~cm} / \mathrm{h}$ to $183.9 \mathrm{~cm} / \mathrm{h}$, based on the bioretention box surface area) as presented in Table 2 . For the first four campaigns, only the water balance variables were monitored, resulting in samples for the qualitative analysis only for campaigns 5 and 6. The samples were collected manually from the weir outlet (outflow) and the tank that receives the percolation flow. The total number of samples collected per campaign is specified in Table 2.

Table 2. Summary of campaigns on the laboratory scale.

\begin{tabular}{ccccc}
\hline & $\begin{array}{c}\text { Dry time } \\
\text { between } \\
\text { campaigns }\end{array}$ & $\begin{array}{c}\mathbf{Q}_{\text {in }} \text { med } \\
(\mathbf{L} / \mathbf{h})\end{array}$ & $\begin{array}{c}\text { Duration } \\
(\mathbf{m i n})\end{array}$ & Qualitative \\
\cline { 5 - 5 } C 1 & - & 1016 & 30 & Nro. samples \\
C 2 & 2 months & 2667 & 12 & - \\
C 3 & 8 days & 1469 & 18 & - \\
C 4 & 1 day & 691 & 27 & - \\
C 5 & 7 days & 1702 & 14 & 10 \\
C 6 & 1 month & 962 & 27 & 10 \\
\hline
\end{tabular}

Flow Rate fixed from laboratory $\left(F_{m}\right)$

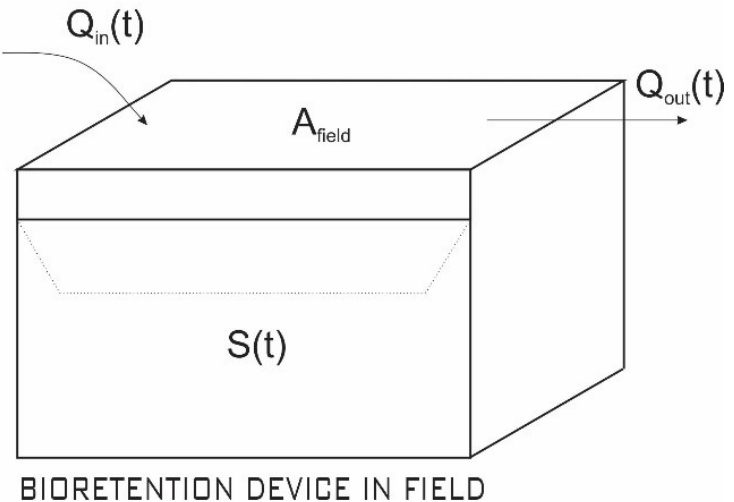

Flow Rate $\left(\mathrm{F}_{\mathrm{m}}\right)$ fixed

Duration $\left(t_{\text {field }}\right)$ fixed to establish a correlation

$$
t_{\text {field }}=\frac{V \cdot 10}{F_{m} \cdot A_{\text {field }}}
$$

Figure 3. Representative scheme of the equivalence relation between the laboratory and field scale. 
Different conditions of initial humidity in the filtering media were also tested, varying the time interval between the campaigns from one day to two months (Table 2). During the experiments, the room temperature was $25^{\circ} \mathrm{C} \pm 2$.

For the field scale study, the inflow was simulated in order to correspond with the average flow rate, previously determined. Then, a controlled event was conducted using a water tank truck serving as a reservoir. The total control volume was $10.12 \mathrm{~m}^{3}$, corresponding to a water depth of $0.43 \mathrm{~mm}$ and an average inflow of $3157.8 \mathrm{~L} / \mathrm{h}$, or a flow rate from $52.0 \mathrm{~cm} / \mathrm{h}$ (based on the bioretention device surface area).

Nine samples were collected to analyze the qualitative parameters on this scale: six samples were collected from the inlet, representing the $\mathrm{M}_{\text {in }}(t)$, and three samples were collected inside the storage, representing the $M_{s}(t)$. As the inflow simulation is done with a control volume relative to $\mathrm{P}(\mathrm{t})$ and $\mathrm{Q}_{\text {in }}(\mathrm{t})$ in a conjugated way, the incoming water quality represents the diffuse pollution found in the runoff and in the direct incident rainfall, even if the latter has a small contribution. In this system, the percolation into the ground is not collected, and consequently, it is not quantified.

\section{RESULTS AND DISCUSSION}

\section{Laboratory scale}

Table 3 shows the water balance results for the bioretention box on a laboratory scale. Except for campaign 2, the flow rate and total volume applied were not sufficient to completely saturate the filtering media and generate outflow in the weir. Only for campaign 2, there was a small outflow, which did not even represent $1 \%$ of the total inlet volume. Therefore, considering all the surveys, the mean water retention efficiency was $99.9 \% \pm 0.2$.

High percolation rates were also found, generally higher than $60 \%$, achieving values of $73.7 \%$. However, for campaigns 1 and 6 , this rate was less significant, achieving only $31.2 \%$ and $39.8 \%$, respectively. These two lower values occurred for the campaigns that took place after a long dry period ( $\geq 1$ month), so that the filtering media was completely dry and, therefore, with a higher retention capability. Regarding campaign 2, even if it also occurred after a long dry period ( 2 months), the mean flow rate (Table 2 ) and total inlet volume (Table 3 ) were the greatest of all campaigns, even leading to outflow. Therefore, it is possible that the filtering media saturated faster, promoting percolation.

To complement the water balance analysis, Figure 4 shows the variation in time for each of the variables in all campaigns.
Considering the bioretention dimensions and a filtering media porosity of $37 \%$, the total net storage volume of the bioretention box is around $500 \mathrm{~L}$. However, the highest peak was found for campaign 2, with a value close to $400 \mathrm{~L}$, which means that the storage peak did not reach the maximum value in any of the experiments. Nevertheless, the percolation hydrographs presented considerable peaks $(25 \mathrm{~L} / \mathrm{min})$ and mean percolation rates for all the experiments. This result indicates that the water retention capability of the system is affected not only by the net volume, but also by the hydraulic conductivity of the ground. Therefore, to calculate the system's amortization capacity, these two factors must be considered in the projects.

Still for campaign 2, in Figure 4 an outflow can be observed, even though the inlet volume did not reach the maximum storage capacity. This can occur because the inflow exceeds the infiltration velocity into the bioretetion box, leading to a runoff in the box itself.

The percolation hydrographs and the temporal variation of storage (Figure 4) indicate a similar behavior between them, with the percolation peak occurring right after the storage peak. From these results, it was also observed that the filtering media maintains the water storage even after the most significant percolation has stopped, remaining almost constant after $120 \mathrm{~min}$.

Overall the results show that bioretention can help reestablish the water balance prior to urbanization (increasing water percolation rates in the ground). Additionally, this conclusion concerning the retention and detention process is important to help sizing and design projects. If we consider the net volume to be sized only as the difference of effective rainfall, or by methods that consider differences between maximum volumes (such as the rain-envelope method), an oversized value is found and, consequently, higher costs.

To better evaluate the water storage process, Figure 5 was made showing the storage areas divided between the soil and sand layers, where the humidity sensors were installed. The soil layer responds more quickly (storage peaks slightly before the sand layer) as it is the first contact of the incoming flow. The sand layer, however, has a greater storage capacity in total volume and with a longer retention time.

In campaigns 5 and 6 , in addition to the water balance analysis of the system, samples were collected to analyze the water quality, increasing the system mass balance and the efficiency in removing pollutants, for the percolation (Table 4).

Campaign 5 shows lower efficiency in removing TOC and higher efficiency for SS, followed by Zn. Regarding all the pollutants, an average range of removal efficiency can be observed,

Table 3. Concentrated water balance. percolation rate and water retention efficiency for laboratory-scale campaigns.

\begin{tabular}{|c|c|c|c|c|c|c|}
\hline & \multicolumn{4}{|c|}{ Total volume (L) / Equivalent depth(mm) } & \multirow{2}{*}{$\begin{array}{c}\text { Percolation } \\
\text { rate }(\%)\end{array}$} & \multirow{2}{*}{$\begin{array}{l}\text { Eff ret } \\
\text { hid. }(\%)\end{array}$} \\
\hline & In & Out & Percolated & Storage & & \\
\hline Campaign 1 & $508.22 / 350.5$ & $0 / 0$ & $163.00 / 112.4$ & $345.22 / 238.1$ & 32.1 & 100.0 \\
\hline Campaign 2 & $533.33 / 367.8$ & $2 / 1.38$ & $357.02 / 246.2$ & $176.31 / 121.6$ & 66.9 & 99.6 \\
\hline Campaign 3 & $421.91 / 291.0$ & $0 / 0$ & $303.20 / 209.1$ & $118.71 / 81.9$ & 71.9 & 100.0 \\
\hline Campaign 4 & $310.74 / 214.3$ & $0 / 0$ & $229.10 / 158.0$ & 81.64 / 56.3 & 73.7 & 100.0 \\
\hline Campaign 5 & $397.05 / 273.8$ & $0 / 0$ & $257.40 / 177.5$ & $139.65 / 96.3$ & 64.8 & 100.0 \\
\hline \multirow[t]{3}{*}{ Campaign 6} & $435.73 / 300.5$ & $0 / 0$ & $173.48 / 119.6$ & $262.25 / 180.9$ & 39.8 & 100.0 \\
\hline & & Media & & & 58.2 & 99.9 \\
\hline & & ard Deviation & & & 17.7 & 0.2 \\
\hline
\end{tabular}


Table 4. Mass balance and pollutant removal efficiency for the laboratory scale.

\begin{tabular}{|c|c|c|c|c|c|c|c|c|c|c|}
\hline & \multicolumn{4}{|c|}{ Campaign 5} & \multicolumn{4}{|c|}{ Campaign 6} & \multirow{3}{*}{$\begin{array}{c}\text { Average } \\
(\%)\end{array}$} & \multirow{3}{*}{$\begin{array}{l}\text { SD } \\
(\%)\end{array}$} \\
\hline & \multicolumn{3}{|c|}{ Total load } & \multirow{2}{*}{$\begin{array}{c}\text { Eff } \\
\text { pollution } \\
\text { retention } \\
(\%)\end{array}$} & \multicolumn{3}{|c|}{ Total load } & \multirow{2}{*}{$\begin{array}{c}\text { Eff } \\
\text { pollution } \\
\text { retention } \\
(\%)\end{array}$} & & \\
\hline & $\mathbf{M}_{\text {in }}(\mathbf{t})(\mathbf{g})$ & $\mathbf{M}_{\mathbf{I}}(\mathbf{t})(\mathbf{g})$ & $\mathbf{M}_{\text {out }}(\mathbf{t})(\mathbf{g})$ & & $\mathbf{M}_{\text {in }}(\mathbf{t})(\mathbf{g})$ & $\mathbf{M}_{\mathbf{I}}(\mathbf{t})(\mathbf{g})$ & $\mathbf{M}_{\text {out }}(\mathbf{t})(\mathbf{g})$ & & & \\
\hline COD & 8.537 & 4.647 & 0 & 45.6 & 1.090 & 2.560 & 0 & -135.1 & -45 & 128 \\
\hline TOC & 3.925 & 3.558 & 0 & 9.4 & 5.280 & 2.840 & 0 & 46.3 & 28 & 26 \\
\hline $\mathrm{PO}_{4}$ & 0.230 & 0.185 & 0 & 19.8 & 0.420 & 0.080 & 0 & 81.6 & 51 & 44 \\
\hline $\mathrm{NO}_{2}^{4}$ & 0.004 & 0.002 & 0 & 44.5 & 0.000 & 0.000 & 0 & 73.5 & 59 & 20 \\
\hline $\mathrm{NO}_{3}^{2}$ & 0.147 & 0.618 & 0 & -320.6 & 0.270 & 0.770 & 0 & -180.5 & -251 & 99 \\
\hline $\mathrm{NH}_{3}^{3}$ & 0.079 & 0.060 & 0 & 24.8 & 0.010 & 0.070 & 0 & -543.2 & -259 & 402 \\
\hline $\mathrm{SS}^{3}$ & 0.199 & 0.004 & 0 & 97.8 & 0.620 & 0.010 & 0 & 97.9 & 98 & 0 \\
\hline $\mathrm{Fe}$ & 2.342 & 5.465 & 0 & -133.3 & 4.260 & 1.510 & 0 & 64.5 & -34 & 140 \\
\hline $\mathrm{Zn}$ & 0.044 & 0.023 & 0 & 47.7 & 0.140 & 0.020 & 0 & 83.4 & 66 & 25 \\
\hline $\mathrm{Pb}$ & 0.036 & 0.020 & 0 & 42.9 & 0.040 & 0.000 & 0 & 97.6 & 70 & 39 \\
\hline $\mathrm{Cu}$ & 0.000 & 0.000 & 0 & - & 0.000 & 0.000 & 0 & - & - & - \\
\hline $\mathrm{Cd}$ & 0.002 & 0.002 & 0 & -26.6 & 0.010 & 0.000 & 0 & 98.2 & 36 & 88 \\
\hline
\end{tabular}
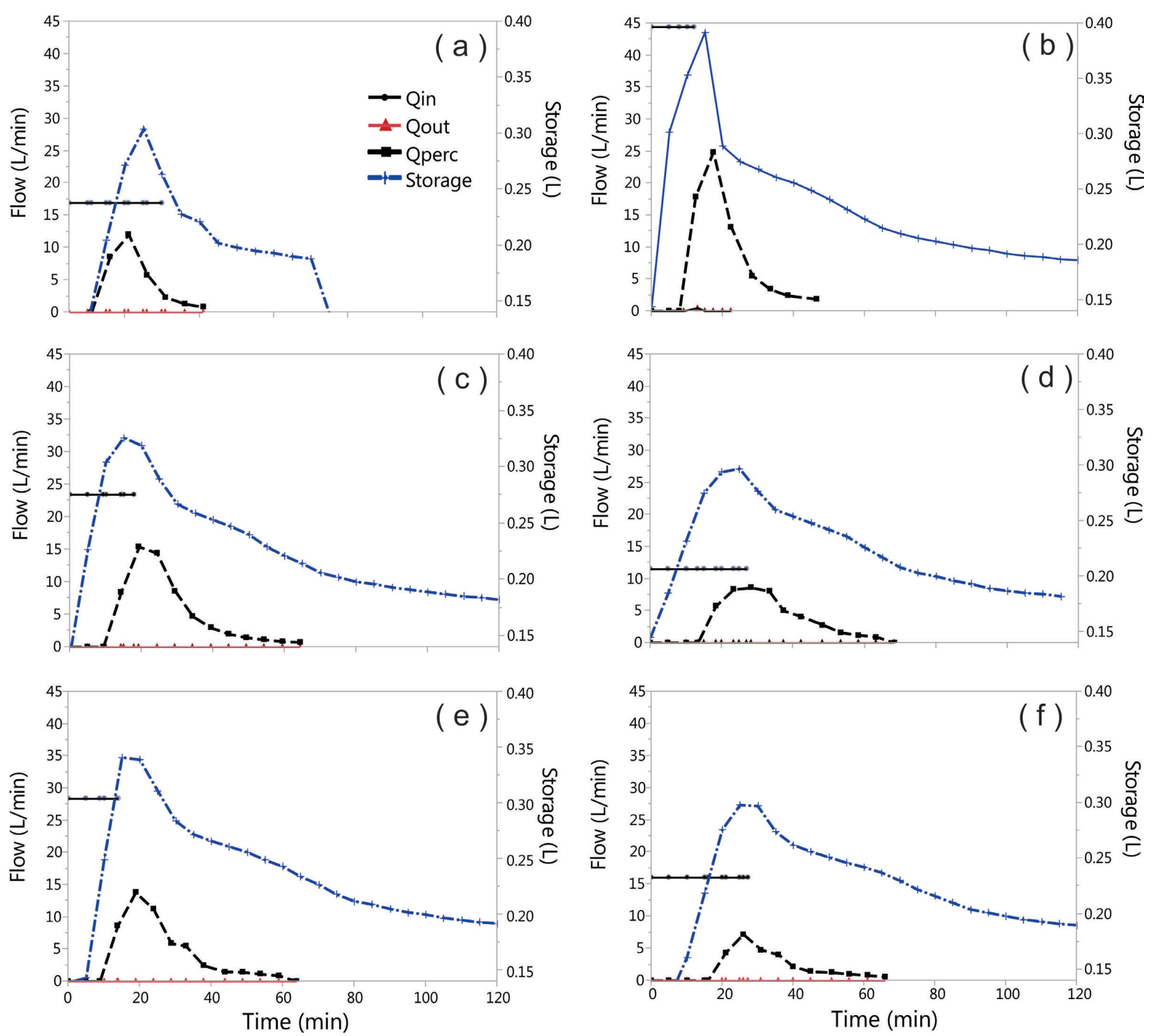

Figure 4. Temporal behavior of the variables' inflow, outflow, storage and percolation in the bioretention box experiment, for: (a) campaign 1; (b) campaign 2; (c) campaign 3; (d) campaign 4; (e) campaign 5 and (f) campaign 6. 

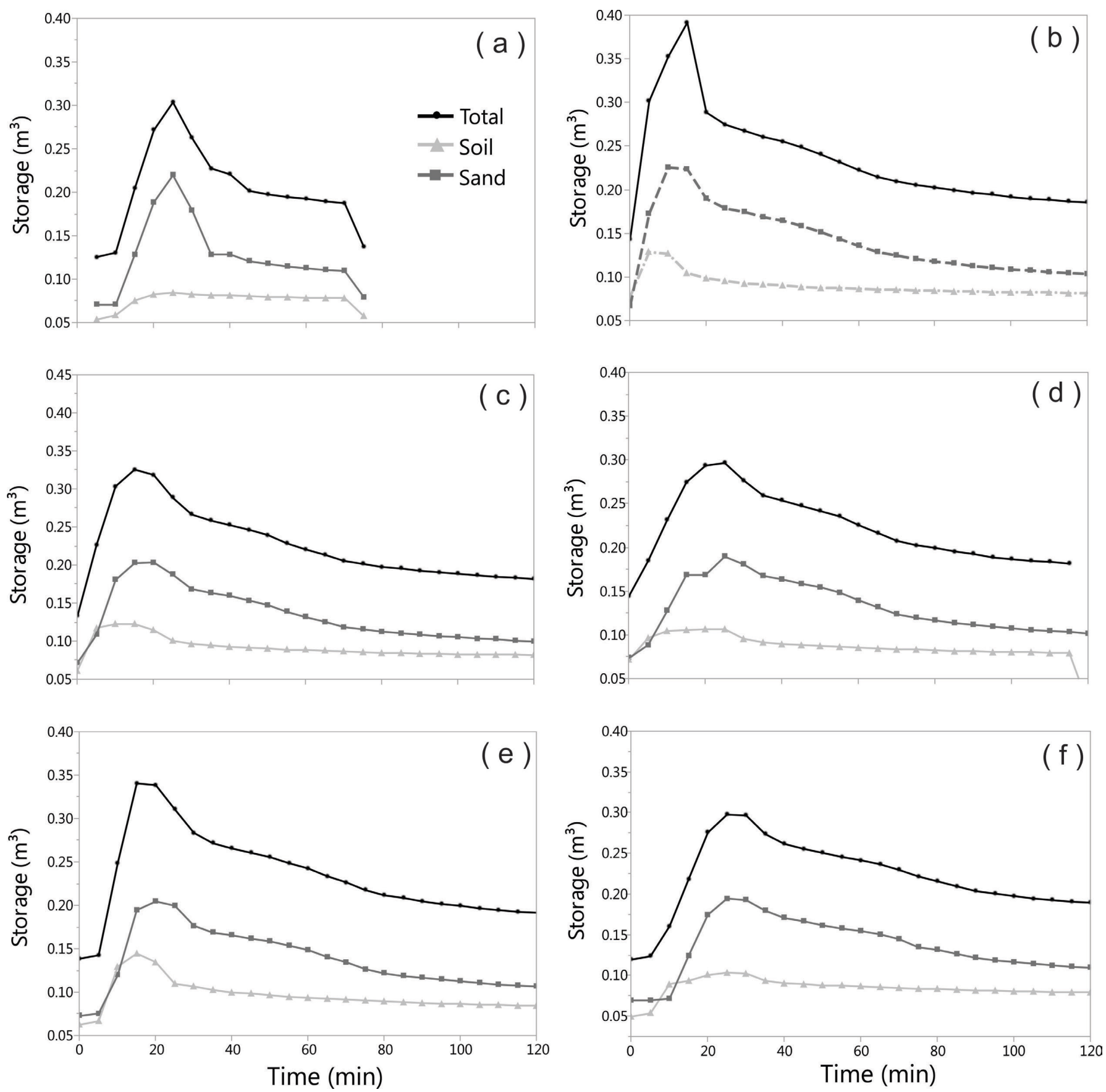

Figure 5. Storage capacity by layers of the bioretention box for: (a) campaign 1; (b) campaign 2; (c) campaign 3; (d) campaign 4; (e) campaign 5 and (f) campaign 6 .

varying from $20 \%$ to almost $50 \%$. This range is low when compared to other studies which also evaluated the laboratory performance and obtained removal rates in the order of $90 \%$ (RYCEWICZ-BORECKI; MCLEAN; DUPONT, 2017; CHAHAL; SHI; FLURY, 2016; WANG et al., 2015, 2016; LIU et al., 2014; BRATIERES et al., 2008). Finally, an export of pollutants was found for $\mathrm{NO}_{3}, \mathrm{Fe}$, and $\mathrm{Cd}$. Fe export probably occurred due to the local soil characteristics, which belong to the oxisol group (characterized by high Fe content). The pollutograph of each pollutant is shown in Figure 6.

When analyzing the results for campaign 6 , the lowest removal efficiency was also for TOC, with $46.3 \%$. However, this value was about $5 \mathrm{x}$ greater than for campaign 5 . A similar behavior occurred for the other pollutants, except for those where we observed export. Despite the increase in removal efficiency when compared to campaign 5, when compared to other laboratory scale studies (already cited) the value of the nutrient removal was still low, not exceeding $82 \%$. For the metals, the efficiency reached values of $98.2 \%$, close to the results observed in other studies. The pollutograph of each pollutant is shown in Figure 7. Still regarding campaign 6 , export was found for parameters COD, $\mathrm{NO}_{3}$ and $\mathrm{NH}_{3}$.

$\mathrm{NO}_{3}$ export in both campaigns was observed. This behavior was also noted in other studies analyzing nutrients. Mangangka et al. (2015) 

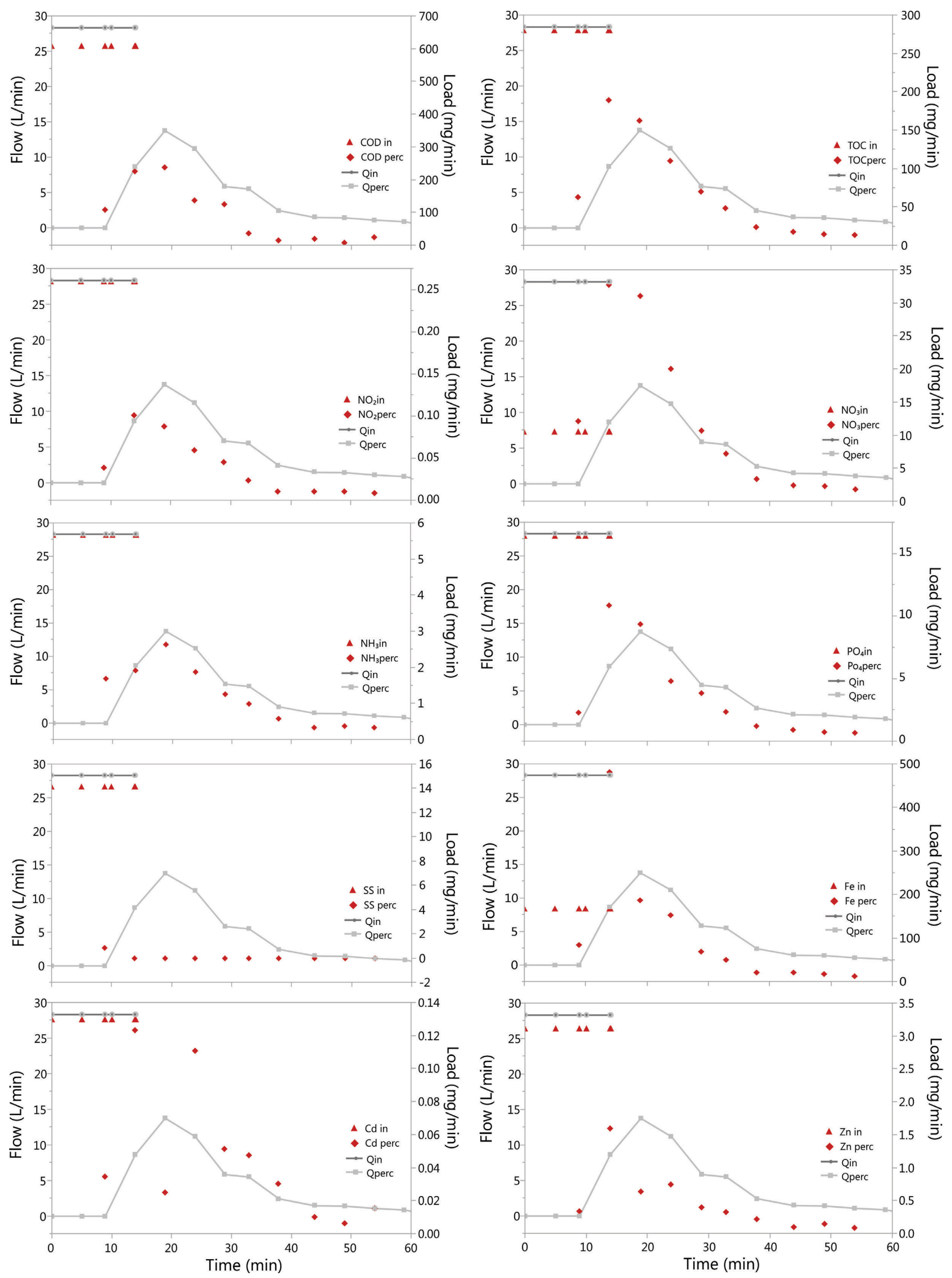

Figure 6. Instant mass balance (pollutographs and hydrographs) for campaign 5. 

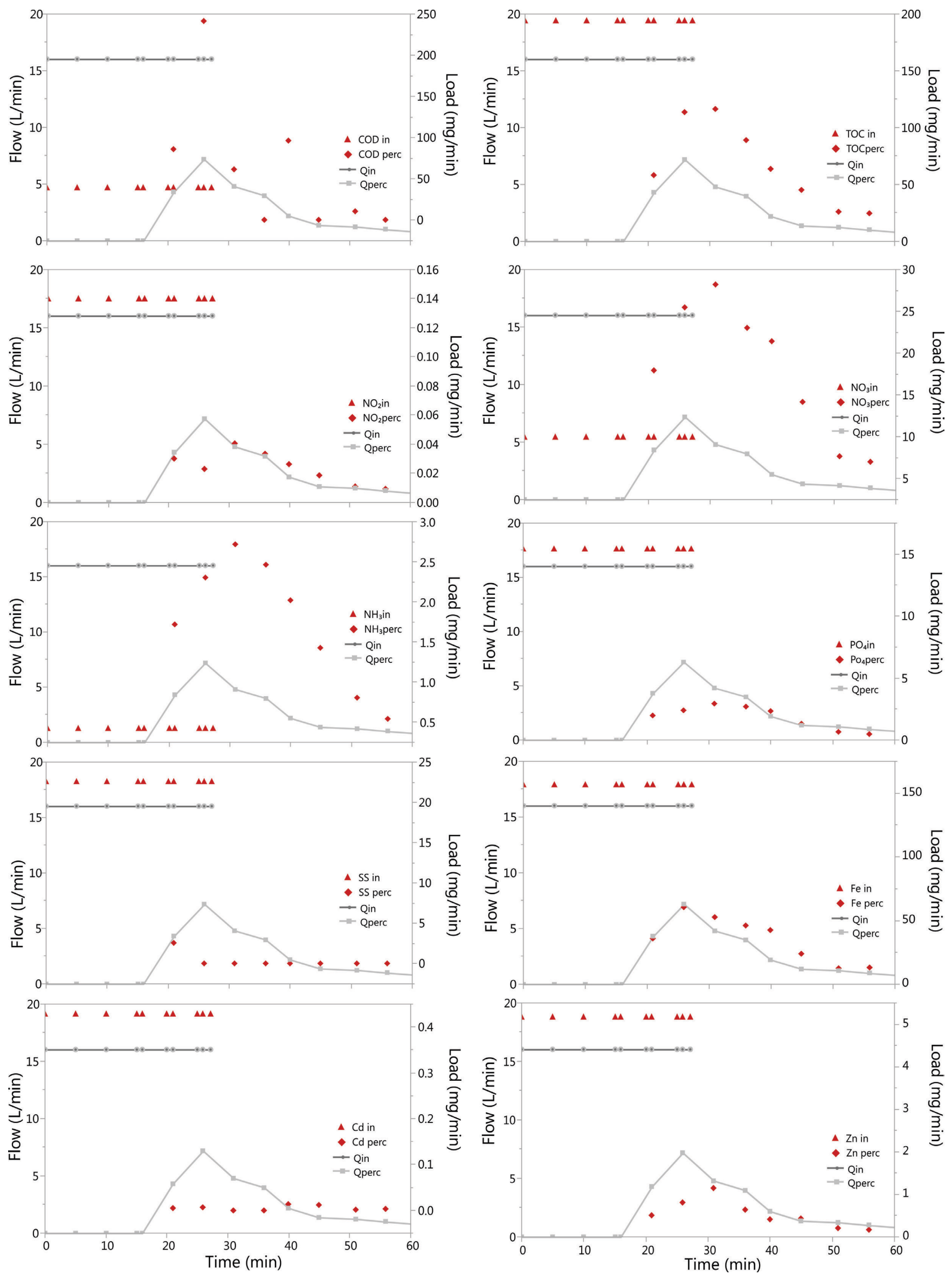

Figure 7. Instant mass balance (pollutographs and hydrographs) for campaign 6. 
analyzed the nitrogen series and they observed that the previously dry period had a primordial role in the treatment, especially for the nitrogen compounds. Long periods of drought contributed to reducing nitrite and ammonia at the device outlet, while it increased the nitrate load, confirming the occurrence of the nitrification process inside the bioretention. Moreover, Davis et al. (2006) and Hsieh, Davis and Needelman (2007) evaluated the nitrogen removal in bioretention cells and observed nitrate export due to biotransformation and nitrification reactions.

For the other pollutants, the difference between the results obtained from the two campaigns can also be explained by the different dry periods prior to the experiment. Campaign 5 took place after 7 days of drought, while for campaign 6 , this period was one month. Therefore, pollutant storage with no degradation in the small period between campaigns 4 and 5 may have occurred, which was then washed away by the percolation during campaign 5. Due to the greater drought time, this behavior did not happen for campaign 6 , justifying the greater removal efficiencies.

\section{Field scale}

Table 5 and Figure 8 present the water balance results for the bioretention application on a field scale. The results show no outflow, representing a water retention efficiency of $100 \%$.

The bioretention device in the field has a surface area of $60.63 \mathrm{~m}^{2}$, a total depth of $3.2 \mathrm{~m}$, an average porosity of $37 \%$ and a storage capacity of $62 \mathrm{~m}^{3}$. Considering the control volume used in the experiment (only $16 \%$ of the total net volume), the storage data shows a negligible volume, not reaching even $0.12 \%$ of the total capacity. On the basis of this result, most of the inlet volume appears to percolate into the ground (percolation rate of $95.3 \%$ ), with almost the same velocity and flow. Figure 8 shows this behavior clearly since curves $Q_{i n}$ and $Q_{\text {perc }}$ overlap almost entirely.

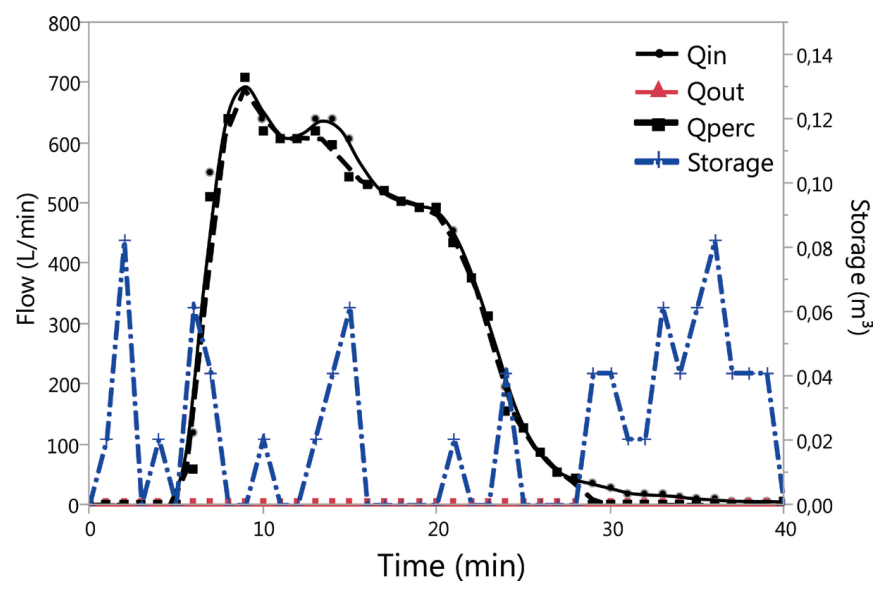

Figure 8. Temporal behavior of the variables' inflow, outflow, storage and percolation, on a field scale event.
However, the storage data were collected by level sensors inside piezometers distributed all along the bioretention basin, dividing them into four equal parts. This form of data collection considers only the net level as volume stored within the bioretention basin. Nonetheless, for low inlet volumes, as in this case, a part of the volume is possibly stored as moisture in the sand layer, which does not generate a net level. Based on this observation, we put forward the hypothesis that the first portion of the bioretention basin retains almost all of this volume, failing to reach the first visit pipe.

Moreover, the expected behavior for the storage was a smooth and increasing curve while there was an increment of water in the device, reaching a peak when there was no further increase (as what occurred for the laboratory scale). Contrary to this, Figure 8 shows a storage behavior with high peak variations in a few minutes. This erratic behavior throughout the experiment is probably due to the representative time scale of each sampled value, which has an intrinsic measurement error.

The study in the field also assessed the pollutant retention efficiency. Water quality samples were collected and analyzed for the inlet $\left(M_{i n}(t)\right)$, which represents the pollution in runoff and for the storage $\left(\mathrm{M}_{\mathrm{S}}(\mathrm{t})\right)$. There was no outflow during the experiment and, consequently, samples of $\mathrm{M}_{\text {out }}(\mathrm{t})$ were not collected.

Table 6 presents a summary of the pollutant mass balance results, including pollutant removal efficiency for the stored water. Despite the higher concentration values for the pollutants in the storage, the total load was low due to the low stored volume. Therefore, we found good results in the removal efficiency, with the lowest value of $87 \%$ for Cd. Regarding the stored water $\left(\mathrm{M}_{\mathrm{S}}(\mathrm{t})\right)$, most of the treatment process had already occurred, such as absorption by plant tissues, soil sorption, filtration through the sand and gravel layers and degradation. Therefore, the removal of some pollutants at this stage is common. In addition, water stored over time will percolate with equal or better quality, as it will still increase soil contact and longer reaction time (DAVIS et al., 2006). However, there was no data monitored for $M_{I}(t)$.

Macedo (2017) also carried out a different study monitoring real rainfall events in this same bioretention device applied in the field. For this study, the results indicated lower values of water retention efficiency (average of $68 \%$ ) and pollutant removal efficiency (around 70\% for all pollutants and exporting for nitrate). The difference in the efficiency values obtained can be explained by the variation in the rainfall intensity and total volume precipitated of the real events monitored, with the flow rate and control volume of the controlled event. The real event ranged from an equivalent depth of $2.6 \mathrm{~mm}$ to $38 \mathrm{~mm}$, while the controlled event was only $0.43 \mathrm{~mm}$. Therefore, the total volume and load to be treated in this experiment were much lower than for what occurred in real events.

Despite the limitations observed when comparing with real events, the results obtained by the controlled event enabled us to advance in some interpretations. Due to the low storage measured,

Table 5. Concentrated water balance. percolation rate and water retention efficiency for field-scale event.

\begin{tabular}{|c|c|c|c|c|c|c|c|c|c|c|}
\hline & \multicolumn{8}{|c|}{ Total volume $\left(\mathrm{m}^{3}\right) /$ Equivalent depth $(\mathrm{mm})$} & \multirow{3}{*}{$\begin{array}{c}\text { Percolation } \\
\text { rate }(\%)\end{array}$} & \multirow{3}{*}{$\begin{array}{c}\begin{array}{r}\text { Eff ret } \\
\text { hid. }(\mathbf{\%})\end{array} \\
100.0\end{array}$} \\
\hline & & & & & Perc & ted & Stc & & & \\
\hline Controlled event & $10.1 /$ & 0.43 & $0 /$ & 0 & $9.77 /$ & 0.41 & $0.042 /$ & 0.0015 & & \\
\hline
\end{tabular}


the importance of the percolation in the retention/detention process could be noted. Moreover, problems could be identified in the monitoring method for small volumes of the storage variable as the level sensor can measure only the volume converted in the liquid depth in the piezometers.

\section{Comparing the scales of analysis}

After evaluating the water balance and mass balance results for the two analysis scales separately, it was important to make a comparative study by raising the limiting factors for a proper comparison. In this study, the condition of equivalence between the scales was made based on the parameters' precipitation equivalent to real events, flow rate and duration, as described in the methodology section. The two scales presented the same design and configuration, but without ensuring geometric, kinematic and dynamic similarity.

At first, the results obtained for the two scales, with the pre-established equivalence parameters, are presented discussing the similarities and differences in the performance results of the systems, listing the possible causes for the differences. Subsequently, care to be taken when extrapolating the results from different scales, and recommendations for future comparative studies are presented.

Table 7 presents a comparison between the retention capacities, input conditions, qualitative and quantitative efficiencies obtained in both evaluation scales. The results indicate that the total control volume and the flow rate range in the scales were insufficient to completely saturate the filtering media, leading to

Table 6. Mass balance and pollutant removal efficiency for field scale. These are the results for the controlled event with Fm of $52 \mathrm{~cm} / \mathrm{h}$, six samples for $\operatorname{Min}(\mathrm{t})$ and three for $\mathrm{MS}(\mathrm{t})$.

\begin{tabular}{lrccc}
\hline & \multicolumn{3}{c}{ Total load } & $\begin{array}{c}\text { Eff pollution } \\
\text { retention }(\%)\end{array}$ \\
\cline { 2 - 4 } & $\mathbf{M}_{\text {in }}(\mathbf{t})(\mathbf{g})$ & $\mathbf{M}_{\mathbf{I}}(\mathbf{t})(\mathbf{g})$ & $\mathbf{M}_{\text {out }}(\mathbf{t})(\mathbf{g})$ & 99.2 \\
$\mathrm{COD}$ & 321.12 & 2.47 & 0.00 & 97.2 \\
$\mathrm{TOC}$ & 133.57 & 3.68 & 0.00 & 95.8 \\
$\mathrm{PO}_{4}$ & 3.14 & 0.13 & 0.00 & 94.5 \\
$\mathrm{NO}_{2}$ & 0.06 & 0.00 & 0.00 & 90.6 \\
$\mathrm{NO}_{3}$ & 10.13 & 0.95 & 0.00 & 91.7 \\
$\mathrm{NH}_{3}$ & 2.93 & 0.24 & 0.00 & 100.0 \\
$\mathrm{SS}$ & 5.03 & 0.00 & 0.00 & 98.6 \\
$\mathrm{Fe}$ & 125.92 & 1.71 & 0.00 & 96.7 \\
$\mathrm{Zn}$ & 1.42 & 0.05 & 0.00 & - \\
$\mathrm{Pb}$ & 0.00 & 0.00 & 0.00 & - \\
$\mathrm{Cu}$ & 0.00 & 0.00 & 0.00 & 87.0 \\
$\mathrm{Cd}$ & 0.11 & 0.01 & 0.00 & \\
\hline
\end{tabular}

no outflow and, consequently, water retention efficiency of almost $100 \%$ in both cases.

For the bioretention box, a control volume greater than the total storage capacity was applied, reaching a value of $106.6 \%$ for the application rate (ratio between the inlet volume and total storage capacity), i.e. a volume exceeding up to $7 \%$. However, storage in the filtering media achieved values around only $80 \%$ of the total capacity. The other portion of volume was converted into percolation, even before the complete saturation of the media.

As for the field scale, the results indicate negligible storage and total percolated volume achieving almost the same value for the inlet volume. However, it was hypothesized that the water was stored as moisture, not generating a liquid level, but still retaining the volume. Regarding the qualitative aspects of the runoff, before and after treatment, the sampling points in the two scales were different. For the laboratory scale, the samples were collected from the percolation outlet, while for the field scale, the samples were collected from the visit pipes. Despite this difference in sampling, both scales can be compared for treatment efficiency as the stored water will percolate at some point, with an equal or high quality since it will still increase soil contact and with a longer reaction time (DAVIS et al., 2006).

Higher removal rates were found for the device in the field, indicating better treatment than the laboratory scale. However, in the literature review, the studies found lower rates of pollutant removal in real-scale applications. The application rate and $\mathrm{H}_{\text {equivalent }}$ explain the difference in the results found in this paper and in the literature. Although the flow rate was the same for the two scales to ensure equivalence, the application rate for the field scale was at least $3 \mathrm{x}$ less than for the laboratory scale. Proportionally, for the bioretention device in the field, the volume to be treated in the same unit of filtering media is lower, leading to a greater treatment.

Moreover, we also compared parameter $\mathrm{H}_{\text {equivalent }}$ for both scales. This parameter represents the height value equivalent to the real bioretention zone responsible for the qualitative treatment, so that the treatment capacities for devices with different scales and configurations could be compared. Its calculation is made by the ratio between the net volume and surface area (shown in Table 1). For this study, $\mathrm{H}_{\text {equivalent }}$ is higher for the field scale than for the laboratory scale, with values of $1.02 \mathrm{~m}$ and $0.32 \mathrm{~m}$, respectively. This means, even at equal application rates in both scenarios, the field scale will still have greater $\mathrm{H}_{\text {equivalent }}$ due to its dimensions, corroborating a better treatment.

The bottom permeability also differs between the two scales, which also influences the performances. The laboratory scale bioretention presents a hollow bottom for the percolated volume collection, not presenting the same difficulty to the flow as the soil generates in the field.

Comparing the results for the two scales, we noticed that even with a hydraulic equivalence through an average flow rate is insufficient to ensure a similarity in the results. For a proper

Table 7. Comparison between the inlet volumes, net volumes and application rate on the laboratory and field scales.

\begin{tabular}{cccccc}
\hline Scale & $\begin{array}{c}\text { Net storage } \\
\text { volume }\left(\mathbf{m}^{3}\right)\end{array}$ & Inlet volume $\left(\mathbf{m}^{3}\right)$ & $\begin{array}{c}\text { Application rate } \\
(\text { in } \% \text { of net volume })\end{array}$ & $\begin{array}{c}\text { Eff quanti } \\
\text { med }(\%)\end{array}$ & $\begin{array}{c}\text { Eff quali } \\
\text { med }(\mathbf{\%})\end{array}$ \\
\hline Laboratory & 0.5 & $0.31-0.53$ & $62.1-106.6$ & 99.9 & -17.0 \\
Field & 62.0 & 10.12 & 16.3 & 100.0 & 95.1 \\
\hline
\end{tabular}


extrapolation of the experiment's results and data in different scales, a study of the dimensional analysis should be carried out, ensuring physical similarity between them. Thus, the geometric similarity should be ensured - with a constant scale factor and equal roughness; kinematic similarity - so that the time intervals used are the same; and dynamic similarity - ensuring dimensionless groups with equal value. Given the physical similarity, it is known that the hydraulic and treatment processes occurring within the devices in the two different scales will be the same.

However, it is known that it is not always possible to ensure a physical similarity between the scales, since the great advantage of the laboratory application is the reduced size, flexibility of layouts and testing new conditions to identify key-factors. Therefore, we present the essential parameters that should be similar for the comparisons and that should be taken into account in the discussion of the results for different scales, mainly in the laboratory and field: (1) Equivalent flow rate - Even though it is an important parameter, it can be observed that it does not ensure similarity in the results by itself. (2) Control volume: the control volume should be established in such a way that the same application rate is applied in both scales. (3) Equivalent net depth $\left(H_{\text {equivalent }}\right)$ : For analysis of the qualitative results, the $\mathrm{H}_{\text {equivalents }}$ of the experimental devices should be close to each other in order to present similar treatment capabilities.

In addition, variations in data acquisition methods can generate undesirable differences in the results, not necessarily related to differences in the scales. In this study, we observed that the different methods for storage acquisition led to misinterpretations regarding the dynamics of bioretention in the field.

\section{CONCLUSION}

From the monitoring of the controlled events, it was possible to obtain efficiency values for the qualitative treatment per pollutant and an average value of water retention efficiency. It is important to remember that these results were obtained for flow rates ranging from $47.5 \mathrm{~cm} / \mathrm{h}$ to $183.9 \mathrm{~cm} / \mathrm{h}$, in relation to the surface area of the two experimental devices:

- For the laboratory scale, we found a water retention efficiency of $99.9 \%$ and percolation rates ranging from $32 \%$ to $76 \%$. Even if the sand layer was not completely saturated, the percolation process occurred. This result indicates the importance of considering the percolation in the retention and detention capacity of bioretention practices. The qualitative analysis demonstrates low pollutant removal efficiency and export for $\mathrm{NO}_{3}$ and $\mathrm{NH}_{3}$. These results are also observed in other studies;

- For the field scale, when comparing with other noncontrolled experiments in the same bioretention, the values for water retention and pollutant removal are significantly higher, indicating a flow rate that corresponds only to small precipitation events. However, these results help to identify the importance of the percolation process in the retention/detention process and problems in quantifying the storage only by the piezometers.
Comparing the two scales of analysis, we identified the main parameters that affect the results for the different scales, which are: the flow rate, the control volume/ application rate and the equivalent net $d e p t h$. For a suitable comparison, these values should be as close as possible between the laboratory-scale and field-scale experimental devices. However, aware of the limitation of laboratory devices and also that the flexibility of layouts is one of its advantages, if these parameters are not similar, they should be observed and taken into account when analyzing the results.

For the experimental devices analyzed in this study, further trials will be required to test a wider range of control volumes and flow rates, which will be able to completely fill the device net volume. On a field scale, methods to measure the sand humidity should be included in order to better analyze the storage, even for small volumes.

\section{ACKNOWLEDGEMENTS}

CAPES 88887.091743/2014-01 (ProAlertas CEPED/USP), CNPq 465501/2014-1 and FAPESP 2014/50848-9 INCT-II (Climate Change, Water Security), CNPq PQ 312056/2016-8 (EESC-USPCEMADEN/MCTIC) and CAPES PROEX (PPGSHS EESC USP), FAPESP 2015/20979-7 Optimization of operation and maintenance of LID practices in subtropical climate.

\section{REFERENCES}

AMERICAN PUBLIC HEALTH ASSOCIATION - APHA. Standard method for water and wastewater examination. 17th ed. Washington: APHA, 1992.

BAPTISTA, M. B.; NASCIMENTO, N. O.; BARRAUD, S. Ténicas compensatórias em drenagem urbana. Porto Alegre: ABRH, 2005. 266 p.

BRATIERES, K.; FLETCHER, T. D.; DELETIC, A.; ZINGER, Y. Nutrient and sediment removal by stormwater biofilters: a large-scale design optimisation study. Water Research, v. 42, n. 14, p. 3930-3940, 2008. PMid:18710778. http://dx.doi.org/10.1016/j. watres.2008.06.009.

BROWN, R. A.; HUNT, W. F. Improving bioretention/biofiltration performance with restorative maintenance. Water Science and Technology, v. 65, n. 2, p. 361-367, 2012. PMid:22233916. http:// dx.doi.org/10.2166/wst.2012.860.

CHAHAL, M. K.; SHI, Z.; FLURY, M. Nutrient leaching and copper speciation in compost-amended bioretention systems. The Science of the Total Environment, v. 556, p. 302-309, 2016. PMid:26977536. http://dx.doi.org/10.1016/j.scitotenv.2016.02.125.

DAVIS, A. P. Field performance of bioretention: water quality. Environmental Engineering Science, v. 24, n. 8, p. 1048-1064, 2007. http://dx.doi.org/10.1089/ees.2006.0190.

DAVIS, A. P.; SHOKOUHIAN, M.; SHARMA, H.; MINAMI, C. Water quality improvement through bioretention media: Nitrogen and phosphorus removal. Water Environment Research, 
v. 78, n. 3, p. 284-293, 2006. PMid:16629269. http://dx.doi. org/10.2175/106143005X94376.

ERICKSON, A. J.; WEISS, P. T.; GULLIVER, J. S. Optimizing stormwater treatment practices: a handbook of assessment and maintenance. New York; Springer, 2013. http://dx.doi.org/10.1007/978-14614-4624-8.

FLETCHER, T. D.; ANDRIEU, H.; HAMEL, P. Understanding, management and modelling of urban hydrology and its consequences for receiving waters: a state of the art. Advances in Water Resources, v. 51, p. 261-279, 2013. http://dx.doi.org/10.1016/j. advwatres.2012.09.001.

GUTIERREZ, L. A. R. Avaliação da qualidade da água de chuva e de um sistema filtro-vala-trincheira de infiltração no tratamento do escoamento superficial direto predial em escala real em São Carlos - SP. 2011. 198 f. Dissertação (Mestrado em Engenharia Urbana) - Universidade Federal de São Carlos, São Carlos, 2011.

HATT, B.; FLETCHER, T.; DELETIC, A. Hydrologic and pollutant removal performance of stormwater biofiltration systems at the field scale. Journal of Hydrology, v. 365, n. 3-4, p. 310-321, 2009. http://dx.doi.org/10.1016/j.jhydrol.2008.12.001.

HSIEH, C. H.; DAVIS, A. P. Evaluation and optimization of bioretention media for treatment of urban storm water runoff. Journal of Environmental Engineering, v. 131, n. 11, p. 1521-1531, 2005. http://dx.doi.org/10.1061/(ASCE)0733-9372(2005)131:11(1521).

HSIEH, C. H.; DAVIS, A. P.; NEEDELMAN, B. A. Nitrogen removal from urban stormwater runoff through layered bioretention columns. Water Environment Research, v. 79, n. 12, p. 2404-2411, 2007. PMid:18044357. http://dx.doi.org/10.2175/106143007X183844.

LAURENSON, G.; LAURENSON, S.; BOLAN, N.; BEECHAN, S.; CLARK, I. The role of bioretention systems in the treatment of stormwater. In: SPARK, D. L. (Ed.). Advances in agrononmy. Philadelphia: Elsevier, 2013.

LI, H.; DAVIS, A. P. Urban particle capture in bioretention media. I: Laboratory and field studies. Journal of Environmental Engineering, v. 134, n. 6, p. 409-418, 2008. http://dx.doi.org/10.1061/ (ASCE)0733-9372(2008)134:6(409).

LIU, J.; SAMPLE, D. J.; OWEN, J. S.; LI, J.; EVANYLO, G. Assessment of selected bioretention blends for nutrient retention using mesocosm experiments. Journal of Environmental Quality, v. 43, n. 5, p. 1754-1763, 2014. PMid:25603260. http://dx.doi. org/10.2134/jeq2014.01.0017.

LUCAS, A. H. Monitoramento e modelagem de um sistema filtro-valatrincheira de infiltração em escala real. 2011. 159 f. Tese (Doutorado) - Universidade Federal de São Carlos, São Carlos, 2011.

LUCAS, A. H.; SOBRINHA, L. A.; MORUZZI, R. B.; BARBASSA, A. P. Avaliação da construção e operação de técnicas compensatórias de drenagem urbana: o transporte de finos, a capacidade de infiltração, a taxa de infiltração real do solo e a permeabilidade da manta geotêxtil. Engenharia Sanitaria e Ambiental, v. 20, n. 1, p. 17-28, 2015. http://dx.doi.org/10.1590/S1413-41522015020000079923.

LUCKE, T.; NICHOLS, P. W. B. The pollution removal and stormwater reduction performance of street-side bioretention basins after ten years in operation. The Science of the Total Environment, v. 536, p. 784-792, 2015. PMid:26254078. http://dx.doi.org/10.1016/j. scitotenv.2015.07.142.

MACEDO, M. B. Optimizing low impact development (LID) practices in subtropical climate. 2017. 89 f. Dissertação (Mestrado em Hidráulica e Saneamento) - Escola de Engenharia de São Carlos, Universidade de São Paulo, São Carlos, 2017.

MAGLIONICO, M. Indagine sperimentale e simulazione numerica degli aspetti qualitativi dei deflussi nelle reti di drenaggio urbano. 1998. $217 \mathrm{f}$. Tese (Doutorado) - Università di Bologna, Bologna, 1998.

MANGANGKA, I. R.; LIU, A.; EGODAWATTA, O.; GOONETILLEKE, A. Performance characterisation of a stormwater treatment bioretention basin. Journal of Environmental Management, v. 150, p. 173-178, 2015. PMid:25490107. http:// dx.doi.org/10.1016/j.jenvman.2014.11.007.

MARENGO, J. A.; SCHAEFFER, R.; ZEE, D.; PINTO, H. S. Mudanças climáticas e eventos extremos no Brasil. Rio de Janeiro: FBDS, 2010. Available from: <http://www.fbds.org.br/cop15/ FBDS_MudancasClimaticas.pdf >.Access on: 1 oct. 2010.

MARSALEK, J.; SCHREIER, H. Innovation in stormwater management in canada: the way forward. Water Quality Resources, v. 44 , n. 1, p. 5-10, 2009.

PETTERSON, S. R.; MITCHELL, V. G.; DAVIES, C. M.; O'CONNOR, J.; KAUCNER, C.; ROSER, D.; ASHBOLT, N. Evaluation of three full-scale stormwater treatment systems with respect to water yield, pathogen removal efficacy and human health risk from faecal pathogens. The Science of the Total Environment, v. 543, n. Pt A, p. 691-702, 2016. PMid:26615487. http://dx.doi. org/10.1016/j.scitotenv.2015.11.056.

ROSA, A. Bioretention for diffuse pollution control in SUDS using experimental-adaptative approaches of ecohydrology. 2016. 109 f. Tese (Doutorado em Hidráulica e Saneamento) - Escola de Engenharia de São Carlos, Universidade de São Paulo, São Carlos, 2016.

RYCEWICZ-BORECKI, M.; MCLEAN, J. E.; DUPONT, R. R. Nitrogen and phosphorus mass balance, retention and uptake in six plant species grown in stormwater bioretention microcosms. Ecological Engineering, v. 99, p. 409-416, 2017. http://dx.doi. org/10.1016/j.ecoleng.2016.11.020.

SANTOS, R. F. Vulnerabilidade ambiental: desastres naturais ou fenômenos induzidos? Brasília: MMA, 2007. 
URBONAS, B.; STAHRE, P. Stormwater: best management practices and detention for water quality, drainage, and CSO management. New Jersey: PTR PH, 1993.

VALVERDE, M. C.; MARENGO, J. A. Mudanças na circulação atmosférica sobre a América do Sul para cenários futuros de clima projetados pelos modelos globais do IPCC AR4. Revista Brasileira de Meteorologia, v. 25, n. 1, p. 125-145, 2010. http://dx.doi. org/10.1590/S0102-77862010000100011.

WANG, J.; ZHANG, P.; YANG, L.; HUANG, T. Adsorption characteristics of construction waste for heavy metals from urban stormwater runoff. Chinese Journal of Chemical Engineering, v. 23, n. 9 , p. 1542-1550, 2015. http://dx.doi.org/10.1016/j.cjche.2015.06.009.

WANG, J.; ZHANG, P.; YANG, L.; HUANG, T. Cadmium removal from urban stormwater runoff via bioretention technology and effluent risk assessment for discharge to surface water. Journal of Contaminant Hydrology, v. 185-186, p. 42-50, 2016. PMid:26826541. http://dx.doi.org/10.1016/j.jconhyd.2016.01.002.

WINSTON, R. J.; LUELL, S. K.; HUNT, W. F. Evaluation of undersized bioretention for treatment of highway bridge deck runoff. In: INTERNATIONAL CONFERENCE ON URBAN DRAINAGE, 12., 2011, Porto Alegre, Brazil. Proceedings... Porto Alegre: IWA, 2011.

YOUNG, C. E. F.; AGUIAR, C.; SOUZA, E. Valorando Tempestades: custo econômico dos eventos climáticos extremos no Brasil nos anos de 2002-2012. São Paulo: Observatório do Clima, 2015.
ZHANG, L.; SEAGREN, E. A.; DAVIS, A. P.; KARNS, J. S. Effects of temperature on bacterial transport and destruction in bioretention media: field and laboratory evaluations. Water Environment Research, v. 84, n. 6, p. 485-496, 2012. PMid:22866389. http://dx.doi.org/10.2175/106143012X13280358613589.

\section{Authors contributions}

Marina Batalini de Macedo: Contributed to the collection and laboratory analysis of quantity and quality samples in the laboratory and in the field, in the data analysis and treatment of water and pollutant load balances, in the discussion and interpretation of the results and writing of the article.

César Ambrogi Ferreira do Lago: Contributed to the collection and laboratory analysis of quantity and quality samples in the laboratory and in the field, in the data analysis and treatment of water and pollutant load balances, in the discussion and interpretation of the results and writing of the article.

Eduardo Mario Mendiondo: Contributed to the construction of the laboratory and field models, in the discussion and interpretation of the results and writing of the article.

Vladimir Caramori Borges de Souza: Contributed to the construction of laboratory and field models, in the data analysis and treatment of water and pollutant load balances and article writing. 